\title{
ADDRESSING OPTIMISM AMONG THE YOUNG INDONESIAN GENERATION IN SUSTAINING THE PANDEMIC
}

\author{
Clara Evi Citraningtyas ${ }^{*}$ \\ ${ }^{1}$ Universitas Pembangunan Jaya, Indonesia \\ *e-mail: clara.citraningtyas@upj.ac.id
}

\begin{abstract}
Abstrak
Pandemi COVID-19 telah sangat memengaruhi dan mengganggu kehidupan orang. Kondisi ini bisa menimbulkan kecemasan dan depresi, terutama di kalangan kaum muda. Padahal menjadi optimis adalah salah satu sikap yang dibutuhkan dalam situasi seperti ini. Karena kaum muda adalah sumber daya masa depan yang penting, optimisme mereka perlu diketahui, dan perlu ditemukan strategi untuk meningkatkannya. Tujuan dari penelitian ini adalah untuk mengidentifikasi adanya optimisme di kalangan generasi muda Indonesia dan bagaimana optimisme tersebut dicapai. Sebanyak 86 mahasiswa usia 17 sampai 21 tahun berpartisipasi dalam studi ini. Pengumpulan data dilakukan melalui survei dan Focus Group Discussion, dengan menggunakan pendekatan kuantitatif dan kualitatif. Hasil studi ini menunjukkan bahwa mayoritas responden menyatakan pesimisme dan mengklaim bahwa pandemi berdampak negatif pada kehidupan, emosi, dan cara pandang masa depan mereka. Sejumlah kecil responden yang menyatakan optimisme kemudian diundang untuk berpartisipasi dalam Focus Group Discussion, dan mereka melaporkan bahwa optimisme mereka berasal dari factor internal (egosentris) dan eksternal (etnosentris). Temuan ini berharga dan penting untuk merancang strategi bagaimana membantu generasi yang terdampak pandemi untuk melangkah maju dengan optimis.
\end{abstract}

Kata kunci: Optimisme; Generasi Muda; Indonesia; Pandemi

\begin{abstract}
The COVID-19 pandemic has utterly devastated our world and has essentially influenced and disrupted people's lives. This condition has resulted in a rise in anxiety and depression, particularly among the young. In such a situation, optimism is essential. Because young people are valuable future assets, it is critical to address their optimism and devise measures to enhance it. This study aims to investigate the presence of optimism among Indonesian youth and how it is achieved. A total of 86 undergraduate students between the ages of 17 and 21 volunteered to participate. This study collects data through a survey and a Focus Group Discussion, using a mixed quantitative and qualitative approach. The findings show that most respondents were pessimistic and claimed that the pandemic harmed their lives, emotions, and future outlook. A limited number of respondents who expressed optimism in the survey were then invited to participate in a Focus Group Discussion, and they reported that their optimism is attained from internal (egocentric) and external (ethnocentric) factors. This finding is valuable and essential for taking action on how to help a generation afflicted by the pandemic move forward with optimism.
\end{abstract}

Keywords: Optimism; Young Generation; Indonesia; Pandemic

This is an open access article under the CC BY-SA license.

Copyright @ 2021 by Author. Published by Universitas Pendidikan Ganesha.

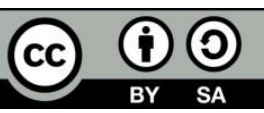

Doi: http://dx.doi.org/10.23887/jish-undiksha.v10i2.33469

Jurnal IImu Sosial dan Humaniora | 279 


\section{INTRODUCTION}

The COVID-19 pandemic has had a significant effect on nearly every area of life. Studies show that the pandemic has an impact on mental health of general population (Tee et al., 2020; Xiong et al., 2020), on children and youth (Courtney et al., 2020; Moore et al., 2020), on education (Dwivedi et al., 2020; Michael Onyema et al., 2020), on employment (Fana et al., 2020), on CSR and marketing (He \& Harris, 2020), and many more. It has also been reported that unemployment during this pandemic is at the highest level since the Great Depression (Petrosky-Nadeau \& Valletta, 2020).

Anxiety, sadness, and other negative emotions including pessimism have increased as a result of this situation. According to a survey undertaken by Leavey et al. (2020), young people are one of the most affected groups. Since young people are important future capital, their quality of life is critical. Brown (2018) discovered that the age range of 16 to 24 years is critical for young people as they lay the groundwork for a stable adulthood. Optimistic young people at this age group will, thus, build a better society, and could pave the way for significant recovery post-pandemic.

Studies indicate that optimism is important for crisis recovery. Optimism is known as an individual difference predictor that represents the degree to which individuals have general positive expectations for the future. It is critical in a person's capacity to react to stress (Carver et al., 2010)

Optimism has been correlated to plenty of powerful, influential, and lifeenhancing aspects. Positive moods, success, perseverance, constructive problem solving, good fitness, and confidence are all associated with general life optimism (Beard et al., 2010). Having optimistic outlook for the future is often crucial in adapting to traumatic or challenging circumstances (GómezMolinero et al., 2018).
Studies have shown the role of optimism in promoting resilience. Tusaie and Patterson (2006), for example, claim that optimism is the most powerful individual predictor of youth resilience. GómezMolinero et al. (2018) also discover that optimism is one of the factors associated with life adaptation that leads to resilience among university students. According to Nes (2016), optimistic people use more problemsolving abilities than pessimistic people, which helps to greater adjustment and functioning in the face of adversity. A study of international students also found a clear positive relationship between optimism and resilience, with optimism playing a substantial role in predicting students' resilience. (Sabouripour \& Roslan, 2015). Moreover, in a 37 years of longitudinal study, Segovia et al. (2012) finds that optimism predicts resilience among repatriated prisoners of war.

The strong correlation between optimism and resilience is obvious, emphasizing the importance of youth positivity during the COVID-19 pandemic. In Indonesia, numerous studies have been conducted to examine the function and influence of optimism. Many studies are being conducted in Indonesia on the role and impact of optimism on business and economy, (Ginting, 2021; HERWANY et al., 2021; Kusumaningrum, Dewi Ayu Hurdawaty \& Yenny, 2020; Oliviaa et al., 2020; Pitoyo et al., 2020), as well as politics and governance (Adinugroho \& Simanjuntak, 2021).

Unfortunately, only a few studies have looked into the impact of the COVID-19 pandemic on the overall optimism of Indonesian youths. Studies on optimism in the context of education are typically linked to online learning or a specific subject. Rahmadi (2021), for example, did a study on online learning that teachers and students have to deal amidst the pandemic. The study involved 572 Indonesian teachers as the respondents. When the work-from-home policy was adopted, most teachers quickly

Jurnal IImu Sosial dan Humaniora | 280 
proceeded to teach remotely. Their optimism and resilience in adopting distance learning during the crisis sends an optimistic signal for future effective adaptation and adoption of distance education. Moreover, Kusmaryono et al. (2020) conducted a study on the level of optimism of students in learning mathematics and the factors that influence students' optimism. Their research was being undertaken from a gender perspective. The subjects of the study were 120 Grade 10 students $(60$ males and 60 females) at State Senior High School 6 Semarang, majoring in Social Sciences. The results showed that optimistic male students outperform female students in terms of academic achievement. It was also found that external and internal variables influence the students' optimism. Abidah et al. (2020), on the other hand, wrote a persuasive paper on inviting the public to be optimistic in facing COVID-19 pandemic by conducting "Merdeka Belajar".

There is a notable paucity of research that investigates the general optimism perspective of the Indonesian young generation during the pandemic. Being positive during the epidemic is more important than ever in our lifetime, and research into the state of optimism among the young generation is required. Furthermore, in order to assist the next generation in moving forward postpandemic, it is critical to determine whether optimism is attained through an internal or external factors, or both.

This study looks into the presence of optimism on young Indonesian perceptions toward life, emotion, excitement, and future perspective. It also looks into how optimistic responders achieve their optimism.

\section{METHOD}

This study employed a mixed quantitative and qualitative analysis of two phases of data collection. The first phase in data collection was survey-based, using Google Forms, distributed to the target group of respondents. The form was disseminated via social media platforms such as WhatsApp, Line, and email. The survey's target respondents were Indonesian young people studying in tertiary institutions at undergraduate level. This group was selected because they are expected to play various key positions in the next generation of leadership.

The survey was carried out in November and December of 2020, when Indonesia was in the tenth month of the pandemic. This span of time was considered appropriate for evaluating people's views of the pandemic's consequences.

An open invitation was distributed to address a series of questions about people's views of their condition during the pandemic and their outlook after the pandemic. Fifteen questions were provided in order to understand how the pandemic influenced their feelings, zeal, and long-term foresight. The questions were designed to determine how optimistic the respondents were about their lives during and in the aftermath of the pandemic. The survey data was quantitatively described to provide snapshots of the respondents' attitude on life, emotion, enthusiasm, and future outlook.

The study received eighty-six responses of 47 male and 39 female undergraduate students between the ages of 17 and 21 . Since the aim of this study was to address the optimistic point of view of youths, it also identified respondents who provided optimistic responses. Ten respondents who were identified to have optimistic outlook were invited to participate in an online Focus Group Discussion (FGD), six agreed to participate. During the FGD, the respondents were questioned on how they obtained their optimistic spirit.

\section{RESULT AND DISCUSSION Impact of COVID-19 on Life}

The first set of questions was aimed at understanding in what way COVID-19 has affected and changed the respondent's life. 
According to a study conducted in the Kingdom of Saudi Arabia on 737 people aged 18 and up (Algahtani et al., 2021), the COVID-19 pandemic has had a considerable impact on numerous elements of people's life quality. To offset the pandemic's negative consequences and improve their living quality, information on the young generation's perceptions of how the epidemic affected their lives is required.

The questions in this study were designed to find young people's perception of how COVID-19 influenced their education, their social life, their family's economy, and their life as a whole. The responses of the respondents are shown in Figure 1.

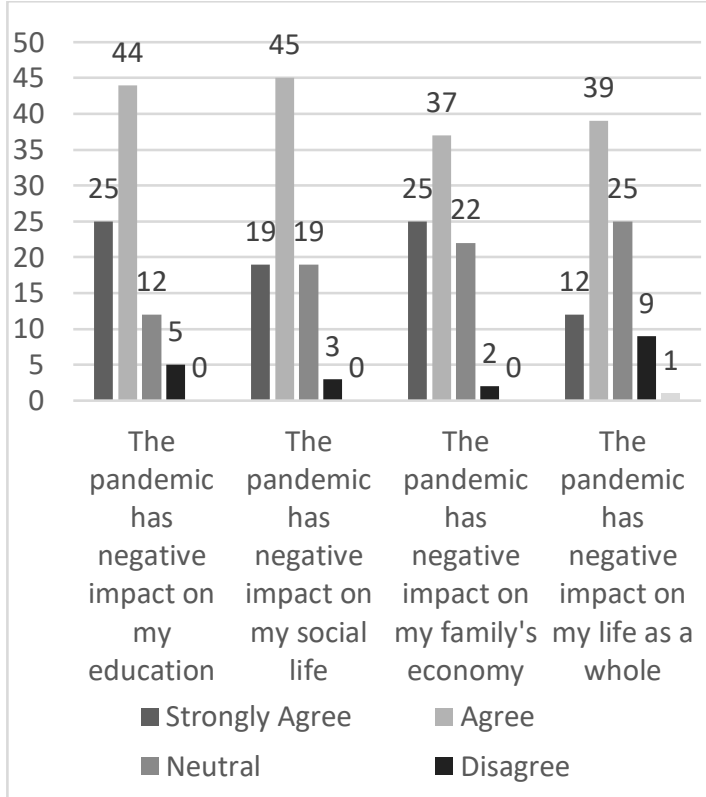

Figure 1 How COVID-19 Impacted Indonesian Youth's Life

The responses on whether COVID-19 had negative impact on the respondents' social life and the family economy were similar. The majority of respondents viewed the pandemic as having a negative effect. A total of $74.4 \%$ of the respondents agreed (52.3\% strongly agreed and $22.1 \%$ agreed) that COVID-19 had negative impact on their social life. A total of $72.8 \%$ agreed $(43.7 \%$ strongly disagreed and $29.1 \%$ agreed) that the pandemic had negative impact on their family economy.

These findings represented the young generation's pessimistic perspective on a challenging situation. The overwhelming majority of respondents had a pessimistic outlook on the impact of COVID-19. None of the respondents identified COVID-19 as having no negative impact on education, social life, or the family economy.

It is important to note, however, that when questioned about the negative impact of the pandemic on their whole life, more respondents (10.5\%) disagreed, and $1.2 \%$ strongly disagreed. This indicated that, despite the hardships they faced during the pandemic, few respondents considered it to be the worst tragedy of their lives. Though small in numbers, the seeds of optimism began here.

\section{Impact of COVID-19 on Emotion}

The second series of questions sought to ascertain if COVID-19 had influenced the respondent's emotions. The emotional state of the young generation is important to address in order to help them. In a US study involving 898 young adults, aged 18 - 30, from mid April to mid May 2020, Liu et.al. (2020) reported high levels of depression (43.3\%), anxiety $(45.4 \%)$, and PTSD symptoms (31.8\%). This is also in line with a data released by U.S. Census Bureau (2021) that during the COVID-19 pandemic, a higher-than-average percentage of young generation (aged 1824) reported anxiety and/or depressed symptoms $(56 \%)$ It is also critical to examine how the pandemic affected Indonesia's youth.

The questions in this study were designed to decide whether the pandemic left the respondents anxious, unable to sleep, unable to study, or easily angered. Figure 2 depicts the responses of the respondents. 


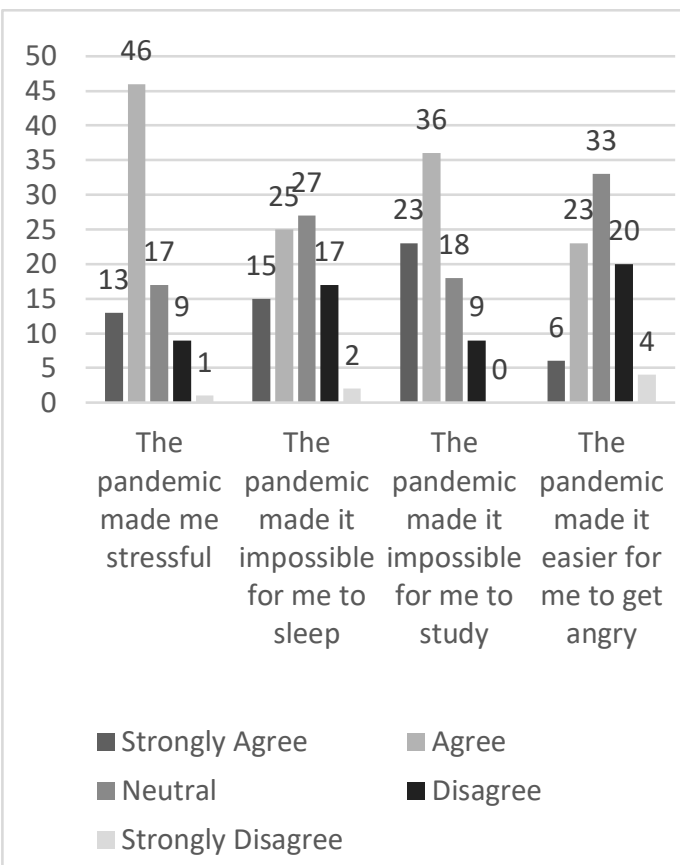

Figure 2 How COVID-19 Impacted Indonesian Youth's Emotion

Again, the large majority of respondents stated COVID-19 had a major impact on their emotions. Respondents typically agreed on the effect of COVID-19 on their stress level, sleep behavior, study pattern, and anger management, according to the findings. The pandemic had left them more stressed, according to $68.6 \%$ of respondents $(15.1 \%$ strongly agreed and $53.5 \%$ agreed). Figure 2 also shows that the effect of COVID-19 on sleep behavior was apparent, but not major. Less than half of the respondents (a total of $46.4 \%$ with $17.4 \%$ strongly agreed, and $29 \%$ agreed) indicated that they faced difficulty in sleeping due to the pandemic. A total of $31.3 \%$ of the respondents indicated that COVID-19 made no impact on their sleep pattern.

COVID-19 did have a substantial effect on respondents' ability to study. A total of $68.5 \%$ of respondents $(26.7 \%$ strongly agreed and $41.8 \%$ agreed) indicated that their capacity to study was impacted. No respondent said that the pandemic made it easier for them to study. In other words, they've all had significant learning challenges. They seem to have had "studysaster" experience as a result of the pandemic. This outcome should serve as a wake-up call to everyone, since being able to study is essential for university students.

It is worth noting that the respondents did not believe the COVID-19 pandemic had any impact on their anger management. Respondents who thought their anger tendency was influenced by the pandemic $(33.7 \%)$ and those who felt their anger tendency was not influenced by the pandemic $(27.9 \%)$ shared a comparable proportion. The majority of respondents $(38.4 \%)$ responded in a neutral, suggesting that the pandemic had little effect on their anger. Overall, the pandemic was challenging for the respondents, but it had little impact on their anger control.

\section{Impact of COVID-19 on Enthusiasm}

The third series of questions aimed to assess whether or not COVID-19 had affected the respondent's enthusiasm. These questions were posed in order to discover evidence of optimism among young people. Although a pandemic may have a negative impact on people's lives, it may also have some beneficial effects. A study by Lee and Rose (2021), found new resilience among young generation during COVID-19 pandemic. As a consequence, looking for a bright light amongst Indonesian youths during this gloomy time is critical to assisting them in overcoming their hardships.

The questions on enthusiasm were structured to determine if respondents saw opportunities during the pandemic. The opportunities addressed were opportunities to grow, to be more creative, to improve skills, to achieve, and to be enthusiastic about reaching more. Figure 3 represents the respondents' reactions. Figure 3 depicts how the pandemic clouded their enthusiasm. Neutrals, disagreements, and strong disagreements dominated the responses, 
which may be interpreted as pessimism. More respondents claimed they firmly disagreed or disagreed with the statements that COVID-19 increased their excitement. Fewer respondents stated that they strongly agreed or agreed that the pandemic presented an opportunity for them to develop, be more creative, enhance their abilities, or achieve accomplishment.

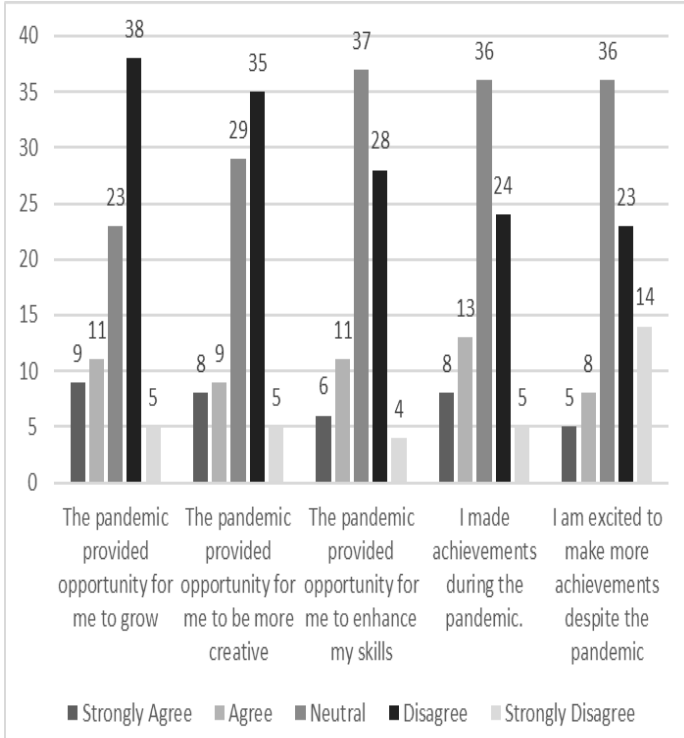

Figure 3 How COVID-19 Impacted Indonesian Youth's Enthusiasm

The least positive opinion was on the respondents' level of excitement in doing more in the face of the pandemic. Only 5.8\% of the respondents strongly agreed, and $9.3 \%$ agreed that they were excited to make more achievements considering the pandemic. The majority of respondents
(52\% in total) disagreed or strongly disagreed on this matter.

These findings showed that a significant majority of respondents were pessimistic in improving themselves during the pandemic. They saw the pandemic as casting a shadow on their enthusiasm. Many young people did not see the pandemic as a source of opportunity or motivation. This is troubling because youths are the nation's future generation. Optimistic youths will build a stronger nation. According to studies (Beard et al., 2010; Gómez- Molinero et al., 2018), optimism promotes goal achievements, successes and progress. Optimists are more likely to report more perceived advancements than pessimists (Monzani et al., 2015). It is thus critical to assist youths in being optimistic.

\section{Impact of COVID-19 on Future Foresight}

The final set of survey questions was designed to measure respondents' future foresight. When it comes to future foresight, a UNICEF report (2020) involving 15,0000 youths from Europe and Central Asia, captured young people's expectations and fears in the face of rapidly changing cultures and economies. This future outlook is crucial for preparing for recovery and hoping for a bright future for young generation. The questions were structured to evoke respondents' views of the nation's economic condition and their outlook for personal success in the next ten years. Figure 4 depicts the responses of the respondents. 


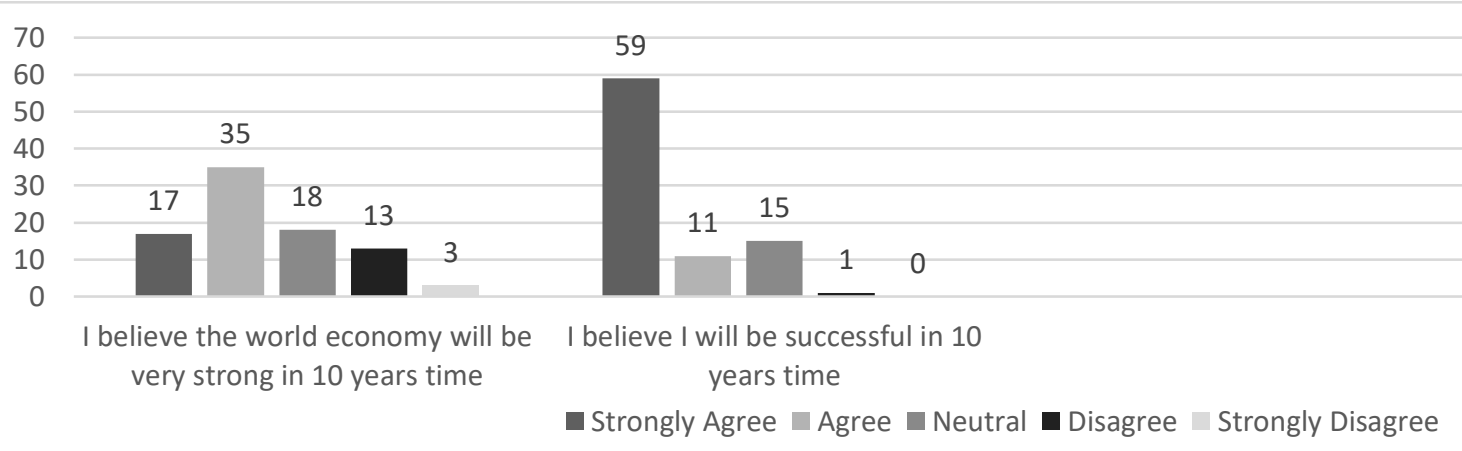

Figure 4 How COVID-19 Impacted Indonesian Youth's Future Foresight

Figure 4 revealed that the majority of the respondents was positive about the state of the global economy and their personal success in ten years. Despite the challenges that the respondents faced during the pandemic, a healthy $65 \%$ predicted that the global economy will be very solid, while just $18 \%$ predicted otherwise. Moreover, respondents were far more confident about their own performance than they were about the success of the global economy. Eighty-one percent of respondents $(81.4 \%)$ believed they would be successful in ten years.

This optimistic future vision is both significant and necessary. According to a report that examined the relationships between potential perceptions, resilience, and effects (Sulimani-Aidan, 2017), optimism and social support are two critical factors. It is therefore advantageous to have young generation who are positive about their future prospects.

\section{FGD with the Optimistic Group}

As this objective of this research was to address youths' optimistic perspectives, those who gave optimistic responses were identified and asked to take part in an online Focus Group Discussion (FGD). Ten were identified, and six respondents agreed to participate in the FGD, where the respondents were asked what made them optimistic and whether they had been trained to be optimistic. Some notable discoveries are described below.

Respondents said they were optimistic because they were surrounded by optimistic people in their lives. They were surrounded by at least one person who was optimistic. They may be a friend, a relative, or a sibling. They believed that these people influenced and impacted them to be optimistic. This is a significant discovery, that optimism can be transmitted and learned.

Furthermore, the FGD participants agreed that they needed to think optimistically in order to move forward. In the wake of the pandemic, they were still positive about the opportunities for progress. They believed that it was possible to make achievements during the pandemic. This finding supports Maheswari and Jutta's study (2020) that in order to enhance resilience, one must increase optimistic and positive thoughts.

Another significant finding was discovered. There was one respondent who had been greatly affected financially by the pandemic. This respondent was a student who needed to work part-time to fund the education, and lost the job as a result of the pandemic. The respondent did not, however, conclude that the pandemic had a negative effect on the respondents' whole life. According to the respondent, the pandemic had an effect on some aspects 
of life, but not the entire life. This respondent's ability to resist generalizing the consequences of the pandemic differed from that of many other respondents, and in itself shed an important light on the importance of point of view.

According to the findings of the FGD, optimism was contagious and can be passed on, taught, and spread to others. Furthermore, optimistic thinking was an effective method for redefine a situation. This optimistic mindset involved how we perceived and acted on circumstances.

\section{CONCLUSION}

It can be concluded that the results of the study lead to an understanding that COVID-19 pandemic have affected and changed the life of Indonesian youths who were the respondents of the study. They viewed that COVID-19 negatively impacted their education, social life, family economy, and their life as a whole. They also indicated that COVID-19 had negatively impacted their stress level, sleep and study pattern, and anger management. Furthermore, the respondents saw that COVID-19 had given them little opportunity to grow, to be more creative, to enhance their skills, and to be enthusiastic to make achievements. However, the respondents were quite optimistic about the world economy and their own successes in ten years' time.

The study also allowed us to learn how respondents attain their optimism. According to the FGD findings, optimism is achieved through positive thinking and can be attained from one's closest person (s). Implication of the present study lies on providing information on Indonesian young generation's perceptions of how the epidemic affected their life. This information is valuable for the government and educational institution to design programs to help a generation afflicted by the epidemic move forward with hope. After all, optimistic young people are critical to paving the road for a significant recovery and a successful nation. This study also demonstrated that to attain optimism is dependent not only on internal personality traits but also on external events. This discovery is significant because it implies that the next generation can be trained to be optimistic.

With these findings, this study opened up an opportunity for more research in our own society, on developing methods or programs to transmit this optimism spirit in young people during and post-pandemic. More researches are needed to complement the generalization of this result. One of this study's limitations is that it was only conducted at the undergraduate level at a university. Future studies should include a larger sample size and a broader geographic scope. This study should also be replicated in other universities in Indonesia.

\section{REFERENCES}

Abidah, A., Hidaayatullaah, H. N., Simamora, R. M., Fehabutar, D., \& Mutakinati, L. (2020). The Impact of Covid-19 to Indonesian Education and Its Relation to the Philosophy of "Merdeka Belajar". Studies in Philosophy of Science and Education, 1(1). https://doi.org/https://doi.org/10.46627/ sipose.v1i1.9

Adinugroho, I., \& Simanjuntak, R. R. (2021). Political trust on Covid-19 handling as predictor towards optimism on new normal situation: Integrity and benevolence rather than competence. Jurnal Psikologi Sosial.

Algahtani, F. D., Hassan, S.-U.-N., Alsaif, B., Zrieq, R., Algahtani, F. D. ; Hassan, S.-U.-N. ;, Alsaif, B. ;, \& Zrieq, R. (2021). Assessment of the Quality of Life during COVID-19 Pandemic: A Cross-Sectional Survey from the Kingdom of Saudi Arabia. Int. J. Environ. Res. Public Health, 18. https://doi.org/10.3390/ijerph18030847

Beard, K. S., Hoy, W. K., \& Woolfolk Hoy Anita, A. (2010). Academic optimism of Jurnal IImu Sosial dan Humaniora| 286 
individual teachers: Confirming a new construct. Teaching and Teacher Education, 26(5), 1136-1144. https://doi.org/10.1016/j.tate.2010.02.0 03

Brown, E. G. (2018). Literature review: young people's transition to a stable adulthood. The Blagrave Trust.

Carver, C. S., Scheier, M. F., \& Segerstrom, S. C. (2010). Optimism. In Clinical Psychology Review (Vol. 30, Issue 7, pp. 879-889). https://doi.org/10.1016/j.cpr.2010.01.00 6

Courtney, D., Watson, P., Battaglia, M., Mulsant, B. H., \& Szatmari, P. (2020). COVID-19 Impacts on Child and Youth Anxiety and Depression: Challenges and Opportunities. Canadian Psychiatric Association, 65(10), 688691.

https://doi.org/10.1177/070674372093 5646

Dwivedi, Y. K., Hughes, D. L., Coombs, C., Constantiou, I., Duan, Y., Edwards, J. S., Gupta, B., Lal, B., Misra, S., Prashant, P., Raman, R., Rana, N. P., Sharma, S. K., \& Upadhyay, N. (2020). Impact of COVID-19 pandemic on information management research and practice: Transforming education, work and life. International Journal of Information Management, 55, 102211.

https://doi.org/10.1016/j.ijinfomgt.2020. 102211

Fana, M., Torrejón Pérez, S., \& FernándezMacías, E. (2020). Employment impact of Covid-19 crisis: from short term effects to long terms prospects. Journal of Industrial and Business Economics, 47, 391-410. https://doi.org/10.1007/s40812-02000168-5

Ginting, A. M. (2021). Optimism Of Positive Economic Growth In 2021 In The Middle Of Covid-19 Pandemic.

Gómez- Molinero, R., Zayas, A., RuízGonzález, P., \& Guil, R. (2018).
Optimism and resilience among university students. International Journal of Developmental and Educational Psychology. Revista INFAD de Psicología., 1(1), 147. https://doi.org/10.17060/ijodaep.2018.n 1.v1.1179

He, H., \& Harris, L. (2020). The impact of Covid-19 pandemic on corporate social responsibility and marketing philosophy. Journal of Business Research, 116, 176-182. https://doi.org/10.1016/j.jbusres.2020.0 5.030

Herwany, A., Febrian, E., Anwar, M., \& Gunardi, A. (2021). The Influence of the COVID-19 Pandemic on Stock Market Returns in Indonesia Stock Exchange. The Journal of Asian Finance, Economics and Business, 8(3), 39-47. https://doi.org/https://doi.org/10.13106/j afeb.2021.vol8.no3.0039

Kusmaryono, I., Maharani, H. R., \& Rusdiantoro, A. (2020). Student's Optimism And Pessimism Against Mathematics Learning Success In The Pandemic Covid-19 Judging From Gender Perspective. Journal Of Critical Reviews, 1(18), 1841-1850.

Kusumaningrum, Dewi Ayu Hurdawaty, R., \& Yenny, M. (2020). Business Optimism in COVID-19 Pandemic Period in Indonesia. South Asian Journal of Social Studies and Economics, 8(3), 13-22. https://doi.org/10.9734/sajsse/2020/v8i 330211

Leavey, C., McNeill, O., Kane, M., \& Aiden, $H$. (2020). The impact of the covid-19 lockdown on young people's health and wellbeing: How are family relationships and emotional support being affected? Youth Voice Journal, 2020(Special issue), 41-56.

Lee, S., \& Rose, R. (2021). Unexpected benefits: new resilience among intergenerational Asian-Americans during the Covid-19 pandemic.

Jurnal IImu Sosial dan Humaniora | 287 
https://doi.org/10.1080/01609513.2020 .1868705

Liu, C. H., Zhang, E., Wong, G. T. F., Hyun, S., \& Hahm, H. "Chris". (2020). Factors associated with depression, anxiety, and PTSD symptomatology during the COVID-19 pandemic: Clinical implications for U.S. young adult mental health. Psychiatry Research, 290, 113172. https://doi.org/10.1016/j.psychres.2020 .113172

Maheshwari, A., \& Jutta, V. (2020). Study of relationship between optimism and resilience in the times of COVID-19 among university students. The International Journal of Indian Psychology, 8(3). https://doi.org/DOI: 10.25215/0803.157

Michael Onyema, E., Chika Eucheria, N., Ayobamidele Obafemi, F., Sen, S., Grace Atonye, F., Sharma, A., \& Omar Alsayed, A. (2020). Impact of Coronavirus Pandemic on Education. 11(13). https://doi.org/10.7176/JEP/1113-12

Monzani, D., Steca, P., Greco, A., D'Addario, M., Pancani, L., \& Cappelletti, E. (2015). Effective pursuit of personal goals: The fostering effect of dispositional optimism on goal commitment and goal progress. Personality and Individual Differences, 82 , 203-214. https://doi.org/10.1016/j.paid.2015.03.0 19

Moore, S. A., Faulkner, G., Rhodes, R. E., Brussoni, M., Chulak-Bozzer, T., Ferguson, L. J., Mitra, R., O’Reilly, N., Spence, J. C., Vanderloo, L. M., \& Tremblay, M. S. (2020). Impact of the COVID-19 virus outbreak on movement and play behaviours of Canadian children and youth: A national survey. International Journal of Behavioral Nutrition and Physical Activity, 17(1). https://doi.org/10.1186/s12966-02000987-8
Nes, L. S. (2016). Optimism, pessimism, and stress. In G. Fink (Ed.), Stress: Concepts, cognition, emotion, and behavior. (pp. 405-411). Elsevier Academic Press.

Oliviaa, S., Gibson, J., \& Rus'an, N. (2020). Indonesia in the Time of Covid-19. Bulletin of Indonesian Economic Studies, 56(2), 143-174. https://doi.org/https://doi.org/10.1080/0 0074918.2020 .1798581

Petrosky-Nadeau, N., \& Valletta, R. G. (2020). An Unemployment Crisis after the Onset of COVID-19.

Pitoyo, A. J., Aditya, B., \& Amri, I. (2020). The impacts of COVID-19 pandemic to informal economic sector in Indonesia: Theoretical and empirical comparison. The 1st Geosciences and Environmental Sciences Symposium (ICST 2020).

Rahmadi, I. F. (2021). Teachers' Technology Integration And Distance Learning Adoption Amidst The COVID-19 Crisis: A Reflection For The Optimistic Future. Turkish Online Journal of Distance Education, 22(2), 26-41.

Sabouripour, F., \& Roslan, S. B. (2015). Resilience, optimism and social support among international students. Asian Social Science, 11(15), 159170.

https://doi.org/10.5539/ass.v11n15p15 9

Segovia, F., Moore, J. L., Linnville, S. E., Hoyt, R. E., \& Hain, R. E. (2012). Optimism predicts resilience in repatriated prisoners of war: A 37-year longitudinal study. Journal of Traumatic Stress, 25(3), 330-336. https://doi.org/10.1002/jts.21691

Sulimani-Aidan, Y. (2017). Future expectations as a source of resilience among young people leaving care. British Journal of Social Work, 47(4), 1111-1127. https://doi.org/10.1093/bjsw/bcw077

Tee, M. L., Tee, C. A., Anlacan, J. P., Aligam, K. J. G., Reyes, P. W. C., Jurnal IImu Sosial dan Humaniora | 288 
Kuruchittham, V., \& Ho, R. C. (2020). Psychological impact of COVID-19 pandemic in the Philippines. Journal of Affective Disorders, 277, 379-391. https://doi.org/10.1016/j.jad.2020.08.04 3

Tusaie, K. R., \& Patterson, K. (2006). Relationships Among Trait, Situational, and Comparative Optimism: Clarifying Concepts for a Theoretically Consistent and Evidence-Based Intervention to Maximize Resilience. Archives of Psychiatric Nursing, 20(3), 144-150.

https://doi.org/10.1016/j.apnu.2005.10. 004

U.S. Census Bureau. (2021). Week 21 Household Pulse Survey: December 9 - December 21, Health Tables. https://www.census.gov/data/tables/20 20/demo/hhp/hhp21.html\#tables

UNICEF, \& European Training Foundation. (2020). Preventing a Lockdown Generation In Europe And Central Asia Building resilient societies with young people in the era of COVID-19.

Xiong, J., Lipsitz, O., Nasri, F., Lui, L. M. W., Gill, H., Phan, L., Chen-Li, D., lacobucci, M., Ho, R., Majeed, A., \& Mclntyre, R. S. (2020). Impact of COVID-19 pandemic on mental health in the general population: A systematic review. In Journal of Affective Disorders (Vol. 277, pp. 55-64). Elsevier B.V. https://doi.org/10.1016/j.jad.2020.08.00 1 